this book, Colin Tudge describes such a finding in "Ida", a forty-seven million year old specimen and the most complete primate fossil ever found. He aims to convey the excitement of this most unusual fossil discovery and describe the importance of the specimen to our understanding of primate evolution. Unearthed by a private fossil collector, the specimen (given the scientific name Darwinius masillae) was unveiled to Norwegian palaeontologist Jørn Hurum and later sold under much secrecy to Oslo's Natural History Museum, where it is currently on display.

The book starts off in prose style, as Tudge tells a story of what might have happened as Ida perished a long time ago in Eocene times, drowning in a lake with unusually fine conditions for specimen preservation. The site is now known as the Messel Pit, a superb location for fossil hunters just $35 \mathrm{~km}$ southeast of Frankfurt, Germany. Once the prosaic tale of Ida is told, the book transforms into a more common form of popular science writing, including detailed descriptions of the specimen itself. However, there is only so much you can tell about a fossil specimen. Tudge expands his book by rather nicely weaving in other aspects of interest, including palaeontology, climate history, the rise of mammals, primate evolution, and ultimately our own evolution as humans. The result is a rather nice glimpse into how evolutionary science, through the addition of a myriad of small puzzle pieces, aims at an overall understanding of the evolution of life on this planet. However, the book feels repetitive at times, and too much emphasis is spent on how fantastic this particular fossil find is. No doubt Ida is a valuable specimen, but as the book was released immediately following the scientific publication describing the find (Franzen et al. 2009), it is simply too early to tell just how valuable; scientific progress is made only via the continuous critical evaluation of new evidence against old, not through self-proclaimed excellence. Critical readers with a background in science will therefore dislike the salesmanship flavour of the The Link. Indeed, Jørn Hurum decided to orchestrate the launch of the fossil in a combined scientific and public event. On the other hand, readers with a non-professional interest in science and in palaeontology in general may enjoy the book as a fascinating story, especially as it touches upon our own history.

\section{Literature Cited}

Franzen, J. L., P. D. Gingerich, J. Habersetzer, J. H. Hurum , W. von Koenigswald, and B. H. Smith. 2009. Complete primate skeleton from the Middle Eocene of Messel in Germany: morphology and paleobiology. PLoS One 4(5): e5723. doi:10.1371/journal.pone. 0005723 .

JOHAN LINDELL

46 Waverley Road, Toronto, Ontario M4L 3T1 Canada

\title{
High-Arctic Ecosystem Dynamics in a Changing Climate: Ten Years of Monitoring and Research at Zackenberg Research Station, Northeast Greenland. Advances in Ecological Research (Volume 40)
}

Edited by H. Meltofte, T.R. Christensen, B. Elberling, M. C. Forchhammer and M. Rasch. 2008. Academic Press, Elsevier, 3251 Riverport Lane. Maryland Heights, Missouri 63043. USA. 596 pages. 105 USD.

This book is packed with information and analyzed data. It may even serve as a "textbook on structure and functioning of a high-arctic ecosystem under climate change". Its 63 contributors keep the promise: great results and findings from diverse disciplines covering 10 years of research in Greenland get delivered to the global audience. The Zackenberg Research Station is one of the few localities where high-detail Arctic research is carried out (together with Abisco, Sweden; Svalbard, Norway; Toolik and Barrow, Alas$\mathrm{ka}$; relevant research stations in Canada, Iceland, and Russia either do not really exist or not well published, synthesized and promoted). And so this book is among the first to report long-term findings in one synthesis volume. Ecological research studies where "more than 1500 physical and biological parameters have been measured annually" and covering an entire decade are generally difficult to come by (only to be compared with other famous research stations such as La Selva in Costa Rica (for instance). Due to the huge climate change discussion, this book provides a great overview and many new facts and viewpoints. In addition, it provides a benchmark to show us where the western countries are standing regarding Arctic science and their effectiveness in monitoring and managing the Arctic which is to be science-based and for sustainability.

During the 10 years of this research, the Arctic warmed already by 2.25 degrees Celsius. With Arctic warming expected to increase up to 8 degrees Celsius, I recommend this book on many accounts: it fits a niche, is very well edited, covers ecosystem components and is a "must have" for people interested in the Arctic, climate change, Greenland, and western science. The introductory and final synthesis chapters alone are great highlights; for instance "the arthropod data set used in this study is probably the most extensive from the entire Arctic"! Another real strength is the use and interpretation of IPCC [Intergovernmental Panel on Climate Change] and (downscaled) climate models. It's made clear in the book text of 563 pages that large-scale temperature events such as NAO [North Atlantic Oscillations] can explain biological effects (e.g., predation and populations) but they are an inherent part of global climate change, and are thus part of the man-made component. 
Most of the 21 chapters and the 13 themes deal with the issues of change in snow melt, snow depth, a longer growing season, the 14-day advance spring season, higher (air) temperature and general variabilities. The notions of ice free lakes, UV radiation and secondary plant metabolites, below-the-ground impacts, and archeology are other great topics to read up on. Links with the marine environment (e.g., sea ice) get elaborated on in detail, and so are many other science topics such as pollination, muskoxen, lemmings, migratory shorebirds (not included are gyrfalcons and most songbirds, though), tadpole shrimp, fish, (introduced) beetles, shrubs, ground-living plants, phenology, glaciers, permafrost, methane release and "weather". The infrared NDVI [Normalized Difference Vegetation Index] remote sensing work and the circumpolar breeding performance of arctic waders I also read with great interest. The chapter summaries provided make an informative text by themselves, highlighting relevant details in each chapter for managers and the lay public that are inclined to skip methodological details, for instance. But I think all audiences will find it rather annoying that the literature references follow a format that actually omits (?!) the publication titles.

The book elaborates on forecasting climate change each of its research topics. But many authors retreat to the argument of "uncertainty" and make conservative understatements for the sake of a wrongly perceived "scientific objectivity", or just use qualitative expert extrapolations, instead of employing science-based quantitative modeling, meta-analysis, the development of new methods (if needed) and the plain use of "common sense".

They should invoke these because (i) the man-made contamination of the atmosphere will certainly not be beneficial, and (ii) the warming trend will result in extinction of local DNA specifically adapted to the Arctic (both are points not made by the Arctic science experts here). Also, it would have been helpful if the editors had insisted on the use of a global taxonomy (e.g., ITIS) so that species and effects can be better described and compared globally.

A detailed index of 12 pages is found at the end of the book. Each book chapter has a nice section of tables and figures (mostly in high-quality color; unfortunately, I could not find a digital version of these to be used for lectures).

This milestone publication is a celebration of the traditional scientific approach, trying to understand biological mechanisms (a là "we sort'em post mortem”) a concept that has proved inefficient worldwide and which did not really halt climate change and loss of species and wilderness. There are a few points where I strongly disagree with the authors. First, this publication has actually more American researchers involved than Greenlanders. Such a lack of native views must represent another rather outdated science concept and expert view that is driven by an "Old Boys" network, mostly being Danish with some Swedish, U.S. and Belgium help (e.g., no Canadian, Icelandic, Norwegian, Finish or Russian co-authors can be seen). Second, this book is basically a (Danish) governmental research exercise (mostly National Environmental Research Institute and University of Copenhagen) that presents us with a selective, and somewhat one-sided, view of "Arctic science". Next, the statistics employed in this book are virtually all linear, additive, correlational (e.g., the misleading notion of "coupling"), and non-spatial (tested hypotheses are often not mentioned or "poor"), whereas it has been known for over 30 years that detectability issues matter and that ecology, climate and the Arctic are complex, non-linear, multivariate, inherently spatial, and require a diversity of approaches to provide us with true progress. Lastly, it comes as a big surprise that this books makes no relevant reference to the International Polar Year (IPY; a major and ongoing planning and global science initiative for many years, and happening when this book was published. Whereas other recent Arctic programs and initiatives such as AMAP [Arctic Monitoring and Assessment Programme], ACIA [Arctic Climate Impact Assessment], ITEX [International Tundra Experiment Program] and ICARPII [International Conference on Arctic Research Planning II] are mentioned). The reader assumes that the great Zackenberg data in the BioBasis database are getting submitted to IPY and will be freely available to the global audience in compatible formats and with high-quality metadata.

This very informative science book should indeed be on your book shelf, and read by many people worldwide. However, if we really want to keep a viable Arctic, we need a better and all inclusive global economy with less growth and resource consumption, compatible and readily available global data sharing, and still have to investigate truly sustainable ways of management and living (none of this has been mentioned, studied or demanded in this book).

FALK HuETtManN

EWHALE lab, Institute of Arctic Biology, Biology \& Wildlife Department, University of Alaska Fairbanks, Alaska 99775 USA

\section{Earth Matters}

Edited by Elinor Greenwood and Elizabeth Haldane. 2008. DK Publishing, 375 Hudson Street, New York, New York 10014 USA. 256 pages, 27.99 USD.

Subtitled "an encyclopedia of ecology", Earth Matters presents a colourful survey of the world's major biomes and biodiversity, aimed at younger readers. As with all Dorling Kindersley books, this one's main 